\title{
Antecedents and consequence of employee turnover intention: Empirical evidence from Ghana
}

\author{
Michael A. Gyensare ${ }^{a *}$, Emmanuel A. Otoo ${ }^{a}$, Joan-Ark Asare ${ }^{b}$ and Evelyn Twumasi ${ }^{\mathrm{c}}$
}

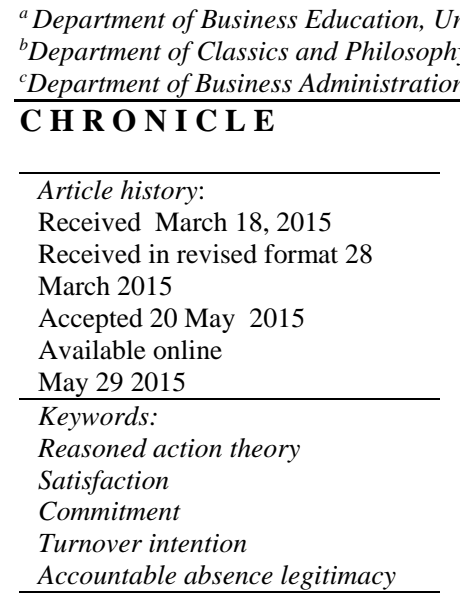

\section{Introduction}

"The challenge today is not just retaining talented people, but fully engaging them, capturing their minds and hearts at each stage of their work lives” (Lockwood, 2007, p.1).

While organizations may differ in the priority they attach to the human resource element in their pursuits to achieve high productivity and gain competitive advantage, they all recognize the value of a qualified, motivated and responsive workforce (Huselid, 1995). Yet, a specific challenge confronting most businesses in the $21^{\text {st }}$ century considering high uncertainty in retaining qualified employees is the issues of employee turnover, and turnover intention (Gyensare, 2013). According to Allen (2008), employee turnover conservatively costs an organization roughly $60 \%$ of an employee's annual salary. Similarly, Vance (2006) reported that Caterpillar, a giant multinational construction equipment manufacturer, saved about $\$ 9$ million in turnover costs alone at one of its European based plants. Like the foregoing statistics, that of Ghana is no different. A survey by The Youth Employment Network (2009) on private sector demand for youth confirmed that high labour turnover rates seem to be the 
most problematic issue in the banking sector, with the sector recording the highest turnover rate of $27 \%$ out of the 26 surveyed sectors in Ghana.

Findings of many previous studies suggest that work-related factors such as job satisfaction (e.g., Onyishi et al., 2012; Samad \&Yusuf, 2012; Yucel \& Bektas, 2012), affective commitment (e.g., Lew \& Sarawak, 2011; Meyer et al., 2012) and normative commitment (e.g., Addae et al., 2008; Schalk \& van Rijckevorsel, 2007) are inversely related to employee turnover intention.

Furthermore, research findings on the turnover intention - absenteeism link are ambiguous and ambivalent (Bycio, 1992; Tharenou, 1993). While some scholars have reported a relationship (e.g., Bussing, Bissels, Fuchs \& Perrar, 1999; Cohen \& Golan, 2007), others have found no relationship (Oshagbemi, 2000; Vogelzang, 2008). To help minimize this ambiguity, Johns (2003) suggests sorting out such complications as a way of providing an opportunity for understanding which is backed by several methods. Interestingly, Koslowsky (2009) in a multi-level model of withdrawal behaviours suggested turnover intention rather than absenteeism as a significant construct that can act both as a predictor and a criterion variable. Consistent with Koslowsky's (2009) proposition, we included turnover intention in our hypothesized model as an antecedent of absence legitimacy which is conceptualized by Addae and Johns (2002) as the extent to which employees perceive absence as an acceptable or accountable work behaviour within the social context in which the behaviour is enacted. The selection of work-related factors (attitude) and absence legitimacy (behaviour) which is mediated by turnover intention (intention) as shown in Figure 1 is based Fishbein and Ajzen (1975) theory of reasoned action. The theory of reasoned action purports that intentions based on reason mediate the relationship between attitude and behaviour (Sheeran, 2002; Sheppard, Harwick \& Warshaw, 1988). As a result, the most immediate and imperative proximal antecedent of absence legitimacy in the current study is turnover intention.

Whereas there is a growing body of research on the linkage between work-related factors and employee turnover intention, the focus of these studies have been in different geographical locations of the world. However, there is a paucity of research in sub-Saharan Africa. The current study will endeavour to address this knowledge gap from a context-specific by analyzing empirical data based on a sample of Ghanaian retail bankers. By so doing, the current study will provide sufficient evidence to the already established link between work-related factors and turnover intention.

In addition, even though Addae et al. (2013) studied a number of antecedents (e.g., work centrality, gender role differentiation, locus of control and time orientation) to absence legitimacy from a crosscultural perspective, their study missed out on a very important proximal antecedent, turnover intention, to absence legitimacy as suggested by the theory of reasoned action (Fishbein \& Ajzen, 1975). The analysis of the effect of turnover intention on absence legitimacy therefore augments Addae et al.'s (2013) study and also enriches the literature on the outcomes of turnover intention from a developing country's perspective.

In conclusion, the goal of this study is to further illuminate the process by which job satisfaction, affective and normative commitment relate to employee turnover intention, which, in turn, relates to absenteeism as a legitimate accountable behaviour. The hypothesized relationships as depicted in Fig. 1 are tested simultaneously using structural equation modeling.

\section{Theory and Hypotheses}

\subsection{Relationship between work-related factors and employee turnover intention}

According to Fishbein and Ajzen's (1975) theory of reasoned action, intention plays key role in the attitude-behaviour nexus. The theory posits that: (a) intention is the most proximal cause of an 
employee's behaviour in the workplace; (b) intention is a function of attitude towards the behaviour and subjective norms; and (c) attitude towards the behaviour is a function of beliefs that the behaviour translate into salient consequences. Sheeran (2002) suggests that the basic idea of Fishbein and Ajzen's theory of reasoned action helps in explaining employee turnover and its antecedent variables. Workrelated antecedents such as job satisfaction, affective and normative commitments are assumed to enhance employees' motivation and involvement with the organization. Hence, an employee's perception of the lack of these factors in the work scenario is more likely to trigger frustration, lassitude and lethargy and finally increase the motivation to withdraw (Gyensare, 2013).

The relationship between work-related factors and employee turnover intention has been empirically examined in many studies, and the findings of most of these studies suggest that job satisfaction, affective commitment and normative commitment are inversely related to employee turnover intention (e.g., Baranik, et al., 2010; Maertz et al., 2007; Meyer et al., 2002; Samad \& Yusuf, 2012; Yucel \& Bektas, 2012).

Walker and Sorce (2009) emphasized that extensive research has been conducted on job satisfaction than any other construct in the extant literature. Job satisfaction is defined as 'a pleasurable or positive emotional state resulting from the appraisal of one's job or job experience' (Locke, 1976, p.1304). However, Chiu and Chen's (2005) study revealed two dimensions of job satisfaction: intrinsic and extrinsic satisfaction. According Chiu and Chen (2005), intrinsic satisfaction refers to factors related to the job itself, such as job independence, job variety, job stability, creativity and sense of responsibility and accomplishment. Extrinsic satisfaction on the other hand refers to employees' satisfaction with factors such as work conditions, policies and praise.

Two significant reasons may help explain the inverse relationship between satisfaction and turnover intent. First, empirical evidence support the notion that employees' perception of the absence of satisfaction often leads to lassitude and lethargy, and consequently reduce commitment. Subsequently, disgruntled employees continually and constantly look for the motivation to escape a dissatisfying employment. These reasons are consistent with Fishbein and Ajzen's (1975) theory of reasoned action which posit that intention plays a key role in the relationship between the attitude of employees and the behaviour they demonstrate in the workplace.

Findings of recent studies suggest that job satisfaction is negatively related to employee turnover intention. For instance, Maqbool et al. (2012) examined the impact of job satisfaction and organizational commitment on the turnover intention of 100 public sector employees from Pakistan. Maqbool and colleagues found a significant inverse relationship between job satisfaction and the turnover intention of public sector employees in Pakistan. Similarly, Onyishi et al. (2012) reported a significant inverse relationship between job satisfaction and employee turnover intention among 200 civil servants in the Benue State of Nigeria. Similar findings have been reported by Rageb et al. (2013) in Egypt, Cohen and Golan (2007) in Israel, Bouckenooghe et al. (2013) in Pakistan and AlBattat and Som (2013) in Malaysia. Consistent with the findings of previous studies, the following hypothesis is proposed:

Hypothesis 1a: Job satisfaction will negatively affect employee turnover intention.

Additionally, a number of studies have explored the link between commitment and employee turnover intention. Allen and Meyer (1990) defined commitment as "a psychological state that binds an individual to an organization” (p.11). Later, Meyer and Allen (1991) realized that commitment could be characterized into three distinct dimensions: affective, normative and continuance. According to Meyer and Allen (1991), affective commitment is an employee's emotional attachment to, identification with, and involvement with the organization whereas normative commitment is referred to as a feeling of obligation to continue with one's employment. Continuance commitment on the other 
hand, is regarded as awareness of the costs associated with leaving the organization. This study however focuses on affective and normative commitment.

Studies relating affective commitment to employee turnover intention are mixed. While some scholars have reported a link between affective commitment and turnover intention (e.g., Guntur, Haerani \& Hasan, 2012; Meyer \& Allen, 1997), others have found no relationship between the two constructs (e.g., Saporna \& Claveria, 2013; Sangroengrob \& Techachaicherdchoo, 2010). In a cross-sectional study at Makassar in Indonesia, Guntur, Haerani and Hasan (2012) found that among the three components of commitment, affective commitment had the highest impact on employee turnover intention. Similarly, Lew and Sarawak (2011) reported a significant inverse effect of affective commitment on the turnover intention of academic staff in Malaysia. A recent study from the Philippines by Fuentes (2013) also found an inverse relation between affective commitment and turnover intention among 95 secondary school teachers in Davao City. However, Saporna and Claveria (2013) studied the turnover intention of employees in the hoteling industry at Philippines and found that all three facets of commitment were not significant antecedents of employee turnover intention. Likewise, Sangroengrob and Techachaicherdchoo (2010) found that commitment had no direct effect on turnover intentions. The authors concluded that even though employees may be highly commitment to their jobs, it is no assurance that they will not leave the organization. Following the foregoing arguments, the following hypothesis is proposed:

Hypothesis 1b: Affective commitment will negatively affect employee turnover intention.

Unlike affective commitment, normative commitment has not received much research attention from organizational behaviour and human resource management practitioners. However, Jaros et al. (1993) point out that attention is now shifting towards normative commitment as an antecedent of turnover cognitions. A number of studies have examined the impact of normative commitment on employee turnover intention and their findings support the notion that normative commitment has an inverse effect on turnover intention. For instance, Schalk and van Rijckevorsel (2007) studied 126 call centre employees in the Netherlands and reported that the direct effect of normative commitment on turnover intention was more pronounced than affective commitment. Similarly, using data from a sample of 255 public service employees from four countries located in the south-eastern part of the United States, Maertz et al. (2007) found a strong significant inverse relationship between normative commitment and turnover intention. The authors concluded that employees with a sense of obligation to the organization have less intention to turnover than those with no obligation to the organization. Similar findings have been reported by Addae et al. (2008) in St. Lucia in the Caribbean Islands, Mehdi, Zahra and Mahshid (2013) in Kazeroon city in Iran, and Yao and Wang (2006) in China. Based on the following findings, the following hypothesis is proposed:

Hypothesis 1c: Normative commitment will negatively affect employee turnover intention.

Even though several studies linking job satisfaction, affective and normative commitment to turnover intention have been conducted, almost all of these studies with the exception of Onyishi et al. (2012) have been conducted elsewhere with sub-Sahara African lacking similar empirical evidence to augment the existing literature. The rarity of such similar studies in sub-Sahara Africa and Ghana specifically, is the logic behind the conceptualization of the link from work-related factors to employee turnover intention in hypothesized model shown in Figure 1.

\subsection{Relationship between turnover intention and accountable absence legitimacy}

Absence legitimacy as a construct has not received much empirical attention in the extant literature. For instance, a small body of extant research (e.g., Harvey \& Nicholson, 1999; Johns, 2010; Johns \& Xie, 1998; Patton, 2011) shows the potential of legitimacy as a useful construct for understanding 
attendance dynamics. In a recent cross-cultural research, Addae et al. (2013) defined legitimacy as having two dimensions - the extent to which absence is perceived as acceptable behaviour and the extent to which people should be held accountable for absence. Further, Addae and Johns' (2002) claim that legitimacy has advantage of being somewhat more proximal to investigated antecedents than actual absence, which is more distal and thus open to a host of confounding antecedents. The current study focuses on the extent to which employee turnover intent relates to the latter part of the definition. Moreover, Addae and Johns (2002) make a case for explicitly investigating the perceived legitimacy of absenteeism across cultures and its relation to values and personality trait variables. Addae et al. (2013) in a cross-cultural study turned their attention to some salient antecedents of absence legitimacy such as work centrality, locus of control, polychronicity, gender roles and social support. However, the authors' missed out on a very salient antecedent, turnover intention, which this study seeks to highlights.

Research on the relationship between turnover intention and absenteeism is ambiguous and ambivalent (Bycio, 1992; Tharenou, 1993). To help lessen this ambiguity, Johns (2003) proposed sorting out such complications as the way of providing an opportunity back by several methods for understanding. Koslowsky (2009) in a multi-level model of withdrawal behaviours suggested that employee turnover intention rather than absenteeism is very significant both as antecedent and consequence variable. Consistent with Fishbein and Ajzen's (1975) theory of reasoned action and Koslowsky's (2009) proposition, turnover intention was included in the hypothesized model as a potential antecedent of absence legitimacy which is conceptualized by Addae and Johns (2002) as the extent to which employees perceive absence as an acceptable or accountable work behaviour within the social context in which the behaviour is enacted.

Berry et al. (2012) indicated that relatively mild behaviours (e.g., turnover intention) can predict future severe behaviours (e.g., absenteeism). Thus, because of the potential for mild behaviours to escalate into more severe behaviours, Berry et al. (2012) suggest that organizations should pay particular attention to these warning signals and invest in strategic interventions to lessen turnover intention which may have an influence on stronger withdrawal reactions such as absenteeism and actual turnover. In a similar vein, some scholars (e.g., Agho et al., 1992; Bussing et al., 1999) have reported that employees who are absent from the job most often are likely to dislike their jobs and leave the organization. Koslowsky et al. (1997) used meta-analytic technique to estimate the bivariate associations among lateness, absence and turnover and then examined their relative strengths, supporting the latenessabsence-turnover progression conclusion. Thus, an individual who intends to turnover will first try lateness, a mild form of behavioural withdrawal reaction, and if circumstances warrant it, continue with absence, and finally if the employee wants to exercise the most extreme form of behavioural withdrawal reaction, decide to leave.

Further, Cohen and Golan (2007) examined the effect of prior absenteeism on later absenteeism and turnover intentions. Using data from a sample of 135 Israeli nurses, Cohen and Golan (2007) found prior absence was strongly related to later absence. They also found a relationship between prior absenteeism and intent to quit but has less impact than it had on later absence. Cohen and Golan (2007) concluded that higher rates of absence provides an early indication of a withdrawal process among employees, and that organizations must treat such information as more than just data on absence rates. In line with this, Borda and Norman (1997) proclaimed that both turnover and absence may be termed physical withdrawal behaviours and are also interrelated because they both stem from the same underpinning motivation to escape a dissatisfying employment (Mitra et al., 1992). Yet, some scholars in the UK (Oshagbemi, 2000), The Netherlands (Guerts et al., 1999), Germany (Staufenbiel \& Konig, 2010) and New Zealand (Vogelzang, 2008) have reported no significant effect of intent to turnover on absenteeism. Accordingly, the following hypothesis is proposed to guide this present study: 
Hypothesis 2: The higher employees' turnover intent, the lower their perception that they should be made accountable for their absence behaviour.

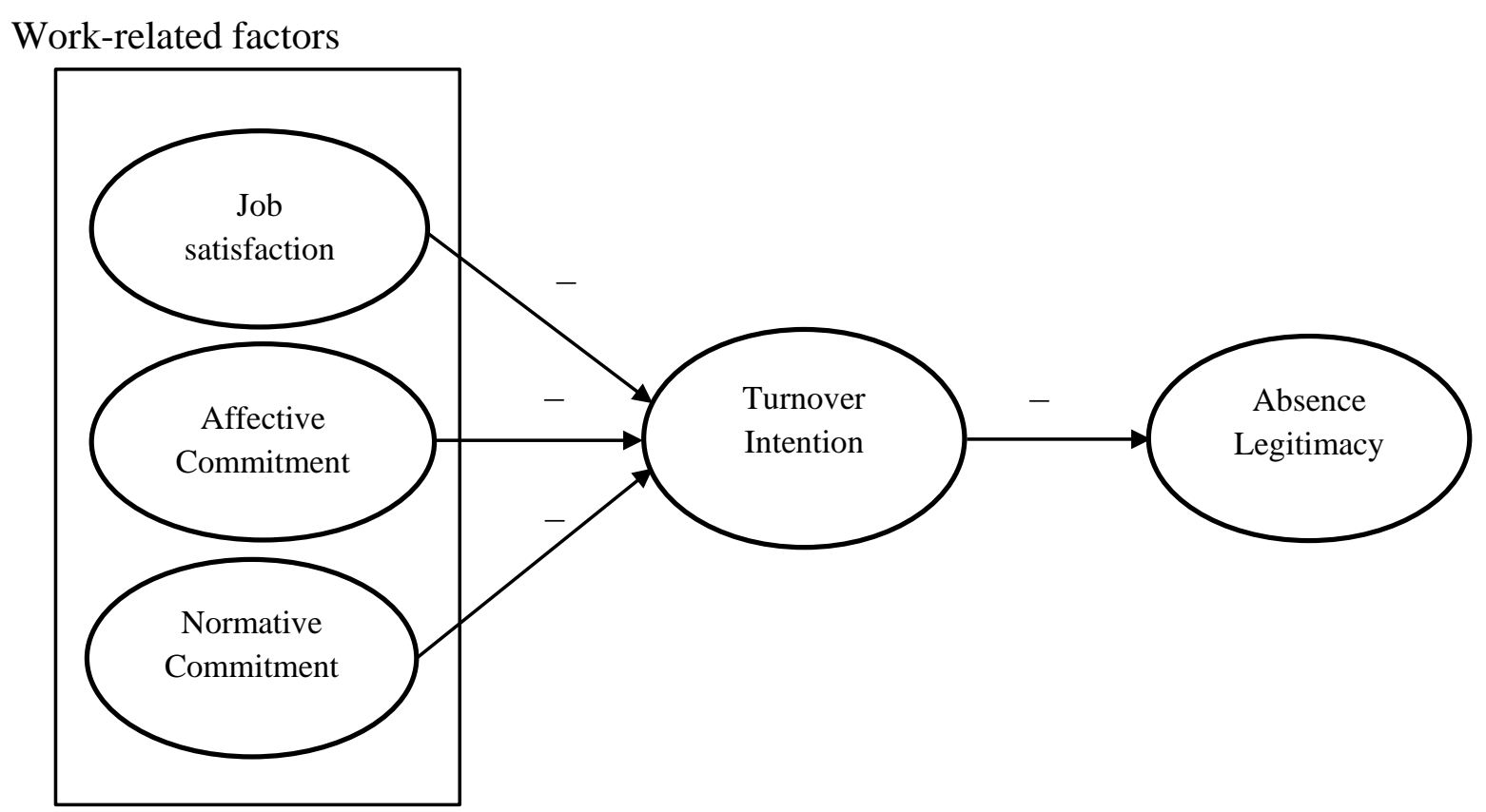

Fig. 1. The hypothesized antecedents and consequence of turnover intention model

\section{Methods}

\subsection{Participants}

The hypotheses in this study were tested with a sample of retail bankers. Participants in the study constituted 416 employees of the retail banking industry in Ghana. Employee data were collected at two different points in time separated by approximately 3 months. Our sample consisted of 65\% employees from Ecobank, 23\% from Barclays and 12\% from Stanbic bank, respectively. Only those employees who have been with the bank for 6 months or longer were eligible to participate in the study. The average age was $28.3(S D=4.5)$; $52 \%$ were male; $72 \%$ were single, and $73 \%$ indicated they had an undergraduate education or higher.

\subsection{Data collection procedure}

Data were collected in two phases, with a 3 month time interval, using a questionnaire. The time period of about 3 month was chosen not to increase the response rate between the two time lags but rather to ensure that potential problems associated with same source bias are alleviated. According to Podsakoff et al. (2012), temporal, proximal, or psychological separation between predictor and criterion reduces common method bias by allowing previously recalled information to leave short-term memory, in essence diminishing respondent's ability and motivation to use his or her prior responses to answer subsequent questions.

\section{Time 1: Work-related factors (job satisfaction, affective commitment and normative commitment)}

At Time 1, July 2013, participants were approached with a package of questionnaires containing the work-related factors and a cover letter from the researchers endorsed by the human resource directorate of each bank. The cover letter explained the purpose of the study, provided assurance of confidentiality and informed participants that they would be receiving additional short questionnaires in 3 months period. We also provided assurances that individual responses would be kept strictly confidential and 
only aggregated data would be reported to the organization, and they were free to decline to participate in the study or to terminate their participant at any time without any queries. A total of 680 surveys were distributed and 465 completed surveys were returned, which translated into a response rate of $68 \%$ for Time 1 .

\section{Time 2: Turnover intention and absence legitimacy}

Approximately 3 months later, September 2013, participants who completed the Time 1 surveys were given a second survey that assessed their turnover intention and perceptions of absence legitimacy. A total of 429 completed surveys were returned. Due to a number of missing data, listwise deletion reduced the sample size to 416 employees who had complete data on both Time 1 and 2.

\subsection{Measures}

\section{Job satisfaction}

A 6-item scale by Agho et al. (1992) was used to measure job satisfaction. The confirmatory factor analysis (CFA) retained only three items with positive and significant higher factor loadings $(\lambda>0.05)$. Sample items from the job satisfaction scale were "I am satisfied with my job" and "I find real enjoyment in my work.” Scale coefficient alpha for the 3-item job satisfaction measure was .72.

\section{Affective commitment}

A 6-item scale from Meyer and Allen (1997) was used to measure affective commitment. These items assessed participants' emotional attachment to and involvement with the organization. Sample item is "I do not feel emotionally attached to this organization (reversed scored)". The 3-item retained by the CFA model recorded a coefficient alpha value of .68.

\section{Normative commitment}

A 6-item scale based on Meyer and Allen (1997) was used to measure normative commitment. Out of the 6 items, only four items had high factor loading above the .50 threshold. A sample item is "I owe a great deal to this organization.” Scale coefficient alpha for the 4-item normative commitment measure was .80 .

\section{Employee turnover intention}

Turnover intention was measured using 3 items developed by Colarelli (1984). All 3 items had positive and higher factor loadings and were therefore retained. A sample item is "I frequently think of quitting my job.” Responses were anchored on a five-point scale ranging from 1(strongly disagree) to 5 (strongly agree). Coefficient alpha for the 3 item turnover intention measure was .79.

\section{Accountable absence legitimacy}

We measured employees' perception of absenteeism using 7-item accountable absence legitimacy scale from the Absence Legitimacy Questionnaire (ALQ; Addae et al., 2013). Only four items were retained after CFA has been conducted. A sample item of the accountable absence legitimacy scale is "Punishing employees for being absent from work is justifiable.” The Cronbach alpha for the 4 item acceptable absence legitimacy scale was .74. 


\section{Analysis and Results}

The descriptive statistics and zero-order correlations among the study variables are presented in Table 1. Job satisfaction correlated with affective commitment $(r=.18, p<.001)$, normative commitment $(r$ $=.20, p<.001)$ and turnover intention $(r=-.22, p<.001)$. Affective organizational commitment related to normative commitment $(r=.23, p<.001)$ and turnover intention $(r=-.25, p<.001)$. Normative organizational commitment correlated with turnover intention $(r=-.36, p<.001)$ and accountable absence legitimacy $(r=.13, p<.01)$. Finally, turnover intention was related to accountable absence legitimacy $(r=-.12, p<.05)$. Hence, results of correlational analyses suggest that in general, the variables in our study were significantly correlated in the expected directions. .Additionally, the correlation coefficients among the study constructs do not exceed .85, indicating that multicollinearity does not appear to be a problem (Gujarati, 2004; Kline, 2005).

\section{Table 1}

Descriptive statistics and zero-order correlation among the study variables

\begin{tabular}{lcccccc}
\hline Variable & Mean & SD & 1 & 2 & 3 & 4 \\
\hline 1. Job satisfaction & 4.86 & 1.02 & -- & & & \\
2. Affective commitment & 4.73 & 1.34 & $0.18^{* * *}$ & -- & & \\
3. Normative commitment & 3.74 & 1.42 & $0.20^{* * *}$ & $0.23^{* * *}$ & -- & \\
4. Turnover intention & 3.01 & 0.89 & $-0.22^{* * *}$ & $-0.25^{* * *}$ & $-0.36^{* * *}$ & -- \\
5. Accountable absence legitimacy & 3.16 & 0.81 & -0.03 & -0.02 & $0.13^{* *}$ & $-0.12^{*}$ \\
\hline Note. $N=416 ;{ }^{*} p<.05,{ }^{* *} p<.01,{ }^{* * *} p<.001$ & & & & & &
\end{tabular}

\subsection{Measurement model validation}

To test the reliability and validity of our study constructs, we used LISREL 8.5 (Jöreskog \& Sörbom, 2006) with maximum likelihood estimation to examine all scales in confirmatory factor analysis (CFA). The evaluation of the measurement model was conducted in two stages. We first conducted a CFA for each individual construct and later CFA for the overall measurement model. Besides, we followed conventional practice (Boso et al., 2013; Cadogan et al., 2006) to analyze the constructs initially in subsets in order to avoid the risk of violating minimum sample size to parameter ratios. As a result, scales that were conceptually related were analyzed together (Baker \& Sinkula, 1999). In all, three subsets were assessed. The first set included the three work-related factors: job satisfaction, affective and normative commitment. The second and third sets contained the items that measured turnover intention and accountable absence legitimacy, respectively.

Following Boso et al. (2013), we used the purification technique to remove several items from the estimated measurement models. Table 2 displays the final list of items, their sources, respective standardized factor estimates and $t$-values as well as reliability and validity indices. First, we assessed the reliability of our constructs by inspecting their internal consistency values and the factor loadings of the items corresponding to that construct (Fornell \& Larcker, 1981). The internal consistency values for all constructs were good, ranging from 0.68 to 0.79 (see Table 2). We then tested the validity of our constructs following recommended procedure (Anderson \& Gerbing; 1988; Bagozzi \& Yi, 2012; Hair et al., 2010). Our five-factor CFA model fits the data, with all fit indices within the accepted threshold $\left(\chi^{2}(109)=320.51, p<0.001\right.$; RMSEA $=0.07$; SRMR $=0.06$; TLI $=0.97$; CFI $\left.=0.95\right)$. As a result, the fit indices of the five-factor model as well as the positive and significant factor loadings reported in Table 2 indicate good convergent validity of our study constructs. Furthermore, we tested for discriminant validity by examining the variance extracted for each construct and the square of the correlations between each construct and the others. The AVE of each construct was far greater than the corresponding inter-construct squared correlations (Hair et al., 2010; Fornell \& Larcker, 1981). Consequently, we concluded that each construct of our study was uniquely distinct from all others. 


\subsection{Assessment of common method bias}

Aside the temporal, proximal or psychological separation (Podsakoff et al., 2012) employed in this study to reduce common method bias, we also followed Podsakoff et al. (2003) recommendation by conducting a Harman's one-factor test using CFA to check for the presence of common method bias. Here, we tested a measurement model in which all the manifest indicators were loaded onto a single latent factor. This model demonstrated extremely poor fit to our data, as shown by the fit indices $\left(\chi^{2}\right.$ $(35)=716.08, p<0.001 ; \chi^{2} / \mathrm{df}=20.46 ;$ RMSEA $=0.22 ;$ SRMR $=0.15 ;$ TLI $=0.36 ;$ CFI $\left.=0.50\right)$ indicating that common method bias would not be a problem to the current study.

\section{Table 2}

Constructs, measurement items and reliability and validity tests

\begin{tabular}{|c|c|}
\hline Item description & $\begin{array}{c}\text { Loadings } \\
\text { (t-values) }^{\mathrm{a}}\end{array}$ \\
\hline \multicolumn{2}{|l|}{ Job satisfaction (Agho, Price \& Muller, 1992): $\alpha=.72 ; \mathrm{CR}=.79 ; \mathrm{AVE}=.56$} \\
\hline - I am satisfied with my job for the time being. & .59 (fixed) \\
\hline - I find real enjoyment in my work. & $.86(10.84)$ \\
\hline - I am often bored with my job (reversed coded). & $.77(11.10)$ \\
\hline \multicolumn{2}{|l|}{ Affective commitment (Meyer \& Allen, 1997): $\alpha=.68 ; \mathrm{CR}=.77 ; \mathrm{AVE}=.52$} \\
\hline - I do not feel like "part of the family” at my organization (reversed coded) & .75 (fixed) \\
\hline - I do not feel “emotionally attached” to this organization (reversed coded) & $.68(8.22)$ \\
\hline - This organization has a great deal of personal meaning for me & $.73(8.12)$ \\
\hline \multicolumn{2}{|l|}{ Normative commitment (Meyer \& Allen, 1997): $\alpha=.80 ; \mathrm{CR}=.80 ; \mathrm{AVE}=.51$} \\
\hline - I would feel guilty if I left my organization now & 64(fixed) \\
\hline - This organization deserves my loyalty & $.72(11.49)$ \\
\hline - I owe a great deal to this organization & $.81(12.19)$ \\
\hline - I do not feel any obligation to remain with my current employer (reversed coded) & $.67(10.92)$ \\
\hline \multicolumn{2}{|l|}{ Turnover intention (Colarelli, 1984): $\alpha=.79 ; \mathrm{CR}=.81 ; \mathrm{AVE}=.59$} \\
\hline - I frequently think of quitting my job & .76 (fixed) \\
\hline - I am planning to search for a new job during the next 12 months & $.90(14.55)$ \\
\hline - If I have my own way, I will be working for this firm one year from now (reverse coded) & $.63(12.30)$ \\
\hline \multicolumn{2}{|l|}{ Accountable absence legitimacy (Addae et al., 2013): $\alpha=.74 ; \mathrm{CR}=.81 ; \mathrm{AVE}=.51$} \\
\hline - It is important for employees to be present on the job every day. & .58 (fixed) \\
\hline - $\quad$ Employee absenteeism should not be tolerated by managers. & $.67(8.23)$ \\
\hline - $\quad$ Punishing employees for being absent from work is justifiable. & $.72(9.01)$ \\
\hline - When employees are absent from work, managers should be upset about it. & $.77(8.92)$ \\
\hline
\end{tabular}

\section{Table 3}

Fit indices for the measurement models

\begin{tabular}{lcccccccc}
\hline CFA model & $\chi^{2}$ & $\mathrm{df}$ & $\chi^{2} / \mathrm{df}$ & $p$-value & RMSEA & SRMR & TLI & CFI \\
\hline Measurement (set 1) & 130.39 & 32 & 4.07 & .00 & .09 & .07 & .89 & .92 \\
Measurement (set 2) & 1.46 & 2 & .73 & $.48^{\mathrm{a}}$ & .00 & .01 & 1.00 & 1.00 \\
Measurement (set 3) & 17.13 & 2 & 8.57 & .00 & .14 & .04 & .95 & .95 \\
Full measurement (set 4) & 320.51 & 109 & 2.94 & .00 & .07 & .06 & .97 & .95 \\
\hline
\end{tabular}

Note. $N=416$, RMSEA = Root mean square error of approximation; SRMR = Standardized root mean square residual; TLI = Tucker-Lewis index; CFI = Comparative fit index; ${ }^{\text {a }}$ Not significant at $\alpha=0.05$.

Measurement (set 1): job satisfaction, affective commitment and normative commitment

Measurement (set 2): turnover intention

Measurement (set 3): accountable absence legitimacy

Full measurement (set 4): all items retained in set 1 through to set 3 were modelled simultaneously. 


\subsection{Structural model estimation}

We used structural equation modelling (SEM) to empirically examine the relationships among the constructs in our study. Following Anderson and Gerbing's (1988) recommendations, we assessed the fit of our hypothesized model by conducting nested models comparison. First, we compared our hypothesized model to a less constrained alternative model with paths added from the work-related factors to accountable absence legitimacy, which would help us to test whether work-related factors exert direct effects on accountable absence legitimacy. Next, we also compared our hypothesized model with a less constrained model whereby paths wee added from the work-related constructs to accountable absence legitimacy, but the path from turnover intention to accountable absence legitimacy was restricted to zero. Consistent with Bagozzi and Yi's (2012) recommendation, the chi-square statistic and four other fit indices were used to assess the fitness of our proposed structural model. The four fit indices used included root mean square error of approximation (RMSEA), standardized root mean square residual (SRMR), Tucker-Lewis index (TLI) and comparative fit index (CFI). Fig. 2 indicates the hypothesized model our study tested. Although attitude behaviour theory (Fishbein \& Ajzen, 1975) posit that intention mediates attitude and behaviour, this study focused on the dual role played by turnover intention as a consequence to the work-related factors on one hand, and antecedent to absence legitimacy on the other hand. Thus, we adopted a more simplified model in this study leaving out more complicated theoretical arguments for future consideration.

Using a sample of 416 employees, results of our study showed that the proposed structural model provided a good fit to the data $\left(\chi^{2}(2)=4.04 ; \mathrm{RMSEA}=0.05 ; \mathrm{SRMR}=0.02 ; \mathrm{TLI}=0.92 ; \mathrm{CFI}=0.98\right)$. Next, we conducted the nested models comparison. We compared the hypothesized model to the two less constrained alternative models. Results suggest that our hypothesized structural model was superior to both the first less restricted alternative model $\left(\chi^{2}(1)=2.42\right.$; RMSEA $=0.08$; SRMR $=0.05$; $\mathrm{TLI}=0.88$; CFI $=0.89$ ) with paths added from work-related factors to accountable absence legitimacy; and the second less restricted alternative model $\left(\chi^{2}(1)=2.50\right.$; $\mathrm{RMSEA}=0.07$; $\mathrm{SRMR}=0.07$; TLI = 0.89; CFI $=0.90$ ), with paths added from the three work-related factors to accountable absence legitimacy and the path from turnover intention to accountable absence legitimacy restricted. Thus, we conclude that based on the fit indices, our hypothesized model explained the data better than the two less restricted alternative models. The final structural equation model together with the standardized estimates is illustrated in Fig. 2.

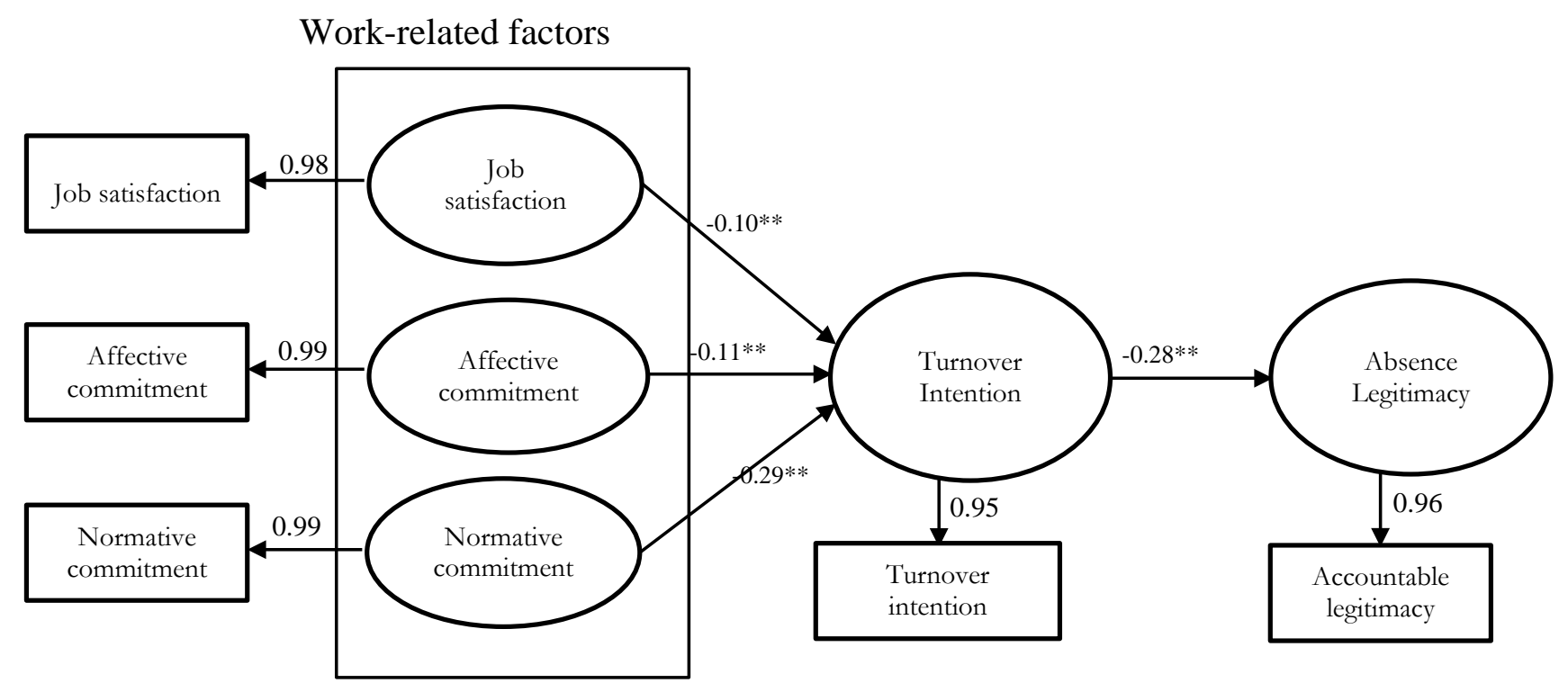

Fig. 2. Final Structural Equation Model 
Model Fit Indices: $\chi^{2}(2)=4.04$; RMSEA $=0.05$; TLI $=0.92$; CFI $=0.98$; SRMR $=0.02$. All structural paths are standardized coefficients and significant $* * p<.01$.

Results in Fig. 2 show that all the hypothesized direct relationships were supported by the data. Thus, it was found that job satisfaction $(\beta=-.10, p<.01)$, affective $(\beta=-.11, p<.01)$ and normative $(\beta=-$ $.29, p<.01)$ commitment had a significant negative relationship with intention to turnover. Hence, empirical support is provided for Hypotheses 1a, 1b and 1c. Further, the results in Figure 2 show that employee turnover intention has a significant effect on accountable absence legitimacy $(\beta=-.28, p<$ $.01)$. As a result, Fig. 2 suggests that Hypothesis 2 is also supported.

\section{Discussion}

At the outset of this paper, we highlighted the ambiguity surrounding the relationship between turnover intention and absenteeism (Cohen \& Golan, 2007; Hayday, 2006; Koslowsky, 2009; Oshagbemi, 2000) as shown in the extant literature. Further, we also indicated that a recent cross-cultural study by Addae et al. (2013) overlooked or downplayed turnover intention as a very significant and salient antecedent of employees perceptions of absence as a legitimate behavior. The current study has addressed these knowledge gaps by investigating the double role played by turnover intention as antecedent to absence legitimacy as well as an outcome to job satisfaction, affective commitment and normative commitment. Consequently, we augment both turnover and absenteeism literatures by extending empirical evidence to developing economies using a sample of Ghanaian retail bankers.

Findings of our study provide additional support for the inverse relations between work-related antecedents and retail bankers' turnover intentions. Consistent with recent empirical findings from developing economies like Nigeria (Onyishi et al., 2012), Pakistan (Bouckenooghe et al., 2013) and Malaysia (AlBattat \& Som, 2013), our analysis found that job satisfaction had a significant inverse effect on turnover intention. Unlike Sangroengrob and Techachaicherdchoo (20110) and Saporna and Claveria (2013) who found no significant linkage between affective commitment and turnover intention, findings of our study support the views of some researchers (e.g. Guntur et al., 2012; Lew \& Sarawak, 2011; Meyer \& Allen, 1997) who reported significant inverse relationship between affective commitment and turnover intention. Similarly, findings of our study showed that normative commitment had significant inverse effects on turnover intention. The inclusion of normative commitment in our postulated model was based on Jaros et al.'s (1993) assertion that normative commitment has received less attention from researchers as compared to affective and continuance commitments.

Since a dissatisfied employee shows less commitment and obligation to the organization, it is imperative that the leadership of the retail banking industry in Ghana, institute policies that seek to enhance employee's attachment and obligation to the organization in order to lessen the cost associated with staff turnover. Also, given the competitive nature of the banking industry and the practice of poaching experience employees by competitors, it behoves management of the banking industry to establish appropriate retention strategies to help maintain their skilled and experienced staff for longer periods.

In addition, several researchers (e.g., Berry et al., 2012; Johns, 2003) have advocated for the need to address ambiguity surrounding the turnover intention-absenteeism nexus through rigorous methodological techniques. The present study addressed this gap by examining the direct effects of turnover intent on absenteeism using structural equation modelling technique. Findings of our study corroborate Koslowsky's (2009) proposition that turnover intention rather than absenteeism is very essential both as an antecedent and consequence variable. But beyond that, our findings also augment Addae et al.’s (2013) cross-cultural study by suggesting turnover intention as a latent and relevant predictor of absence legitimacy. Similarly, findings of our study are consistent with the logic of 
reasoned action theory (Fishbein \& Ajzen, 1975) and evidence from previous investigations (e.g., Cohen \& Golan, 2007) concerning the link between turnover intention and absenteeism.

Finally, we found that turnover intent accounted for $65 \%$ of the variation in absence legitimacy. The findings of our study extend the absence legitimacy theory. First, we argue that if an employee decides to quit the organization, he/she may begin to exhibit the intention through frequent absence from work and thus perceive the absence behavior as legitimate without being made accountable for it. The higher an employee's intention to turnover, the less accountable is the perception of his/her absence behavior. As a result, reducing employee turnover intention in the banking sector has the propensity to reduce absenteeism and thus make the employee accountable for his/her absence behavior.

\section{Conclusion}

In this study, we examined the effects of work-related antecedents on turnover intention on one hand and turnover intention as an antecedent of perceptions of accountable absence legitimacy on the other hand. The findings enriched our knowledge of the significant effects of turnover intention on the perceptions of absence legitimacy. Further, we also added to the extant literature by showing the predictive powers of job satisfaction, affective commitment and normative commitment on employee turnover intention. Even though our findings have undeniably enhanced our understanding of the double role of turnover intention as both consequence variable and potential antecedent of absence legitimacy from the Ghanaian context, our findings should be treated as preliminary until future research replicates them with larger samples from both private and public organizations.

Further, our study conceived work-related antecedents to include job satisfaction, affective and normative commitments. While these may be key antecedents which have been linked with diminishing turnover intention, future research, specifically in sub-Sahara Africa, should examine a different set of antecedents such as employee engagement and psychological climate in order to confirm whether the negative effects reported in this study are replicated across an array of work-related antecedents of turnover intention. Future study should also consider the potential positive effects of turnover intention on absenteeism through acceptable absence legitimacy. Likewise, our findings limited to professionals in the Ghanaian retail banking sector and therefore cannot be inferred to the entire Ghanaian context let alone sub-Sahara Africa. Future longitudinal and experimental research across other public and private sector organizations in Ghana and beyond would clearly help confirm the structural paths examined in our study.

Finally, it is possible for common method bias to have invalidated the findings since our study variables were assessed with self-report measures. However, considering our methodological approach (i.e., data collection approach, CFA and SEM analytical techniques) and the fact that the correlations among the main variables are fairly reasonable, it is uncertain that, common method bias is responsible for the relationships observed in our study.

In spite of its mark of distinction as the beacon of hope in Africa; there is a paucity of empirical management research in Ghana. As a result, we hope that the findings reported here, demonstrating the inverse effect of work-related antecedents on turnover intention on one hand, and an inverse effect of turnover intention on accountable absence legitimacy on the other hand, will stimulate further management research in Ghana.

\section{References}

Addae, H.M. \& Johns, G. (2002). National culture and perceptions of absence legitimacy. In M. Koslowsky \& M. Krausz (Eds.), Voluntary employee withdrawal and inattendence: A current perspective (pp.20-50). New York, NY: Springer.

Addae, H.M., Johns, G. \& Bois, K. (2013). The legitimacy of absenteeism from work: A nine nation exploratory study. Cross Cultural Management, 20(3), 402-428. 
Addae, H.M., Parboteeah, K.P. \& Velinor, N. (2008). Role stressors and organizational commitment: Public sector employment in St. Lucia. International Journal of Manpower, 29(6), 567-582.

Agho, A.O., Price, J.L. \& Mueller, C.W. (1992). Discriminant validity of measures of job satisfaction, positive affectivity and negative affectivity. Journal of Occupational and Organizational Psychology, 65(3), 185-196.

Ajzen, I. \& Fishbein, M. (2000). Attitudes and the attitude-behaviour relation: Reasoned and automatic processes. European Review of Social Psychology, 11(1), 1-33.

AlBattat, A.R.S. \& Som, A.P. (2013). Employee dissatisfaction and turnover crises in the Malaysian hospitality industry. International Journal of Business and Management, 8(5), 62-71.

Allen, D.G. (2008). Retaining talent: A guide to analyzing and managing employee turnover. Alexandria, VA: SHRM Foundation.

Allen, N.J. \& Meyer, J.P. (1990). The measurement and antecedents of affective, continuance, and normative commitment to the organization. Journal of Occupational Psychology, 63, 1-18.

Anderson, J.C. \& Gerbing, D.W. (1988). Structural equation modeling in practice: A review and recommended two-step approach. Psychological Bulletin, 103(3), 411-423.

Bagozzi, R.P. \& Yi, Y. (2012). Specification, evaluation, and interpretation of structural equation models. Journal of Academy of Marketing Science, 40, 8-34.

Baker, W.E. \& Sinkula, J.M. (1999). The synergistic effects of market orientation and learning orientation on organizational performance. Journal of the Academy of Marketing Science, 27(4), 411-427.

Baranik, L., Roling, E.A. \& Eby, L.T. (2010). Why does mentoring work? The role of perceived organizational support. Journal of Vocational Behaviour, 76(3), 366-373.

Berry, C., Lelchook, A. \& Clark, M. (2012). A meta-analysis of the interrelationships between employee lateness, absenteeism, and turnover: Implications for models of withdrawal behaviour. Journal of Organizational Behaviour, 33, 678-699.

Borda, R.G. \& Norman, I.J. (1997). Factors influencing turnover and absence of nurses: A research review. International Journal of Nursing Studies, 34, 385-394.

Bouckenooghe, D., Raja, U. \& Butt, A.N. (2013). Combined effects of positive and negative affectivity and job satisfaction on job performance and turnover intentions. The Journal of Psychology: Interdisciplinary and Applied, 147(2), 105-123.

Bussing, A., Bissels, T., Fuchs, V. \& Perrar, K.M. (1999). A dynamic model of work satisfaction: Qualitative approaches. Human Relations, 52(8), 999-1028.

Bycio, P. (1992). Job performance and absenteeism: A review and meta-analysis. Human Relations, 45, 193-220.

Cadogan, J.W., Cui, C.C., Morgan, R.E. \& Story, V.M. (2006). Factors facilitating and impeding the development of export market-oriented behaviour: A study of Hong Kong manufacturing exporters. Industrial Marketing Management, 35, 634-647.

Chang, W-J, A., Wang, Y-S., \& Huang, T-C. (2013). Work design-related antecedents of turnover intention: A multilevel approach. Human Resource Management, 52(1), 1-26.

Chiu, S. \& Chen, H. (2005). Relationship between job characteristics and organizational citizenship behaviour: The mediational role of job satisfaction. Social Behaviour and Personality, 96(3), 619632.

Cohen, A. \& Golan, R. (2007). Predicting absenteeism and turnover intentions by past absenteeism and work attitudes. Career Development International, 12(5), 416-432.

Colarelli, S.M. (1984). Methods of communication and mediating processes in realistic job previews. Journal of Applied Psychology, 69, 633-642.

Fishbein, M. \& Ajzen, I. (1975). Belief, attitude, intention, and behaviour: An introduction to theory and research. Reading, MA: Addison-Wesley.

Fornell, C., \& Larcker, D. (1981). Evaluating structural equation models with observable variables and measurement error. Journal of Marketing Research, 18, 39-50. 
Fuentes, R. (2013). The influence of demographics, organizational commitment and burnout towards the turnover intentions of teachers. Southeast Asian Interdisciplinary Research Journal, 1(1), 145158.

Guerts, S.A., Schaufeli, W.B. \& Rutte, C.G. (1999). Absenteeism, turnover intention and inequity in the employment relationship. Work and Stress, 13(3), 253-267.

Gujarati, D.N. (2004). Basic econometrics (4th ed.). New York: McGraw-Hill.

Guntur, R.M.Y., Haerani, S. \& Hasan, M. (2012). The influence of affective, continuance and normative commitments on the turnover intentions of nurses at Makassar's private hospitals in Indonesia. African Journal of Business Management, 6(38), 10303-10311.

Gyensare, M.A. (2013). Employee turnover intention: Empirical examination of antecedent and outcome variables. A master's thesis, Department of Organization and Human Resource Management, University of Ghana, Legon, Ghana.

Hair, J.F., Black, W.C., Babin, B.J., \& Anderson, R.E. (2010). Multivariate data analysis: A global perspective ( $7^{\text {th }}$ ed.). London: Pearson.

Hansung, K. \& Stoner, M. (2008). Burnout and turnover among social workers: Effects of role stress, job autonomy and social support. Administration in Social Work, 32(3), 5-25.

Harvey, J. \& Nicholson, N. (1999). Minor illness as a legitimate reason for absence. Journal of Organizational Behaviour, 20, 979-993.

Hayday, S. (2006). Managing absence effectively. IES Opinion. Retrieved January 15, 2014, from http://www.employment-studies.co.uk.

Huselid, M.A. (1995). The impact of human resource management practices on turnover, productivity, and corporate financial performance. Academy of Management Journal, 38,635-672.

Jaros, S., Jermier, J., Koehler, J. \& Sincich, T. (1993). Effects of continuance, affective and moral commitment on the withdrawal process: An evaluation of eight structural equation models. Academy of Management Journal, 47, 951-995.

Johns, G. \& Xie, J.L. (1998). Perceptions of absence from work: People’s Republic of China versus Canada. Journal of Applied Psychology, 83, 515-530.

Johns, G. (2003). How methodological diversity has improved our understanding of absenteeism from work. Human Resource Management Review, 13,157-184.

Johns, G. (2010). Presenteeism in the workplace: A review and research agenda. Journal of Organizational Behaviour, 31, 519-542.

Jöreskog, K. G., \& Sörbom, D. (2006). LISREL 8.8 for windows. Lincolnwood, IL: Scientific Software International, Inc.

Koslowsky, M. (2009). A multi-level model of withdrawal: Integrating and synthesizing theory and findings. Human Resource Management Review, 19,283-303.

Koslowsky, M., Sagie, A., Krausz, M. \& Dolman, A. (1997). Correlates of employee lateness: Some theoretical considerations. Journal of Applied Psychology, 82, 79-88.

Lew, T-Y. \& Sarawak, M. (2011). Affective organizational commitment and turnover intention of academics in Malaysia. International Conference on Business and Economic Research, 1, 110-114.

Locke, E.A. (1976). The nature and causes of job satisfaction. In M.D. Dunnette (Ed.), Handbook of industrial and organizational psychology (pp.1297-1349). Chicago, IL: Rand McNally.

Lockwood, N.R. (2007). Leveraging employee engagement for competitive advantage: HR's strategic role. HR Magazine, 52(3), 1-11.

Maertz, C.P., Griffith, R.W., Campbell, N.S. \& Allen, D.G. (2007). The effects of perceived organizational support and perceived supervisor support on employee turnover. Journal of Organizational Behaviour, 28, 1059-1075.

Maqbool, F., Murtaza, G. \& Rehman, A.U. (2012). Moderating role of organizational commitment between job satisfaction and turnover intentions. European Journal of Scientific Research, 82(4), 564-571.

Mehdi, R., Zahra, P. \& Mahshid, N. (2013). Job satisfaction and organizational commitment among nurses. Life Science Journal, 10(5s), 1-5. 
Meyer, J. P. \& Allen, N.J. (1997). Commitment in the workplace. Thousand Oaks, CA: Sage Publications, Inc.

Meyer, J.P. \& Allen, N.J. (1991). A three-component conceptualization of organizational commitment. Human Resource Management Review, 1, 61-98.

Meyer, J.P., Stanley, D.J., Herscovitch, L. \& Topolnytsky, L. (2002). Affective, continuance, and normative commitment to the organization: A meta-analysis of antecedents, correlates, and consequences. Journal of Vocational Behaviour, 61(2), 20-52.

Meyer, J.P., Stanley, D.J., Herscovitch, L. \& Topolnytsky, L. (2002). Affective, continuance, and normative commitment to the organization: A meta-analysis of antecedents, correlates, and consequences. Journal of Vocational Behaviour, 6(2), 20-52.

Mitra, A. Jenkins, G.D. Jr. \& Gupta, N. (1992). A meta-analysis review of the relationship between absence and turnover. Journal of Applied Psychology, 77, 879-889.

Moynihan, D.P. \& Landuyt, N. (2008). Explaining turnover intention in state government: Examining the roles of gender, life cycle, and loyalty. Review of Public Personnel Administration, 28(2), 120143.

Onyishi, I.E., Ucho, A., \& Mkavga, T. (2012). Job satisfaction, gender, tenure, and turnover intentions among civil servants in Benue State. Interdisciplinary Journal of contemporary Research in Business, 3(11), 378-387.

Oshagbemi, T. (2000). Is length of service related to the level of job satisfaction? International Journal of Social Economics, 30(12), 1210-1232.

Patton, E. (2011). The devil in the details: Judgments of responsibility and absenteeism from work. Journal of Occupational and Organizational Psychology, 84, 759-779.

Podsakoff, P.M., MacKenzie, S.B. \& Podsakoff, N.P. (2012). Sources of method bias in social science research and recommendations on how to control it. Annual Review of Psychology, 63, 539-569.

Rageb, M.A., Abd-El-Salam, E.M., El-Samdicy, A. \& Farid, S. (2013). Organizational commitment, job satisfaction and job performance as a mediator between role stressors and turnover intentions: A study from an Egyptian cultural perspective. The Business and Management Review, 3(2), 52-73.

Samad, S. \& Yusuf, S.Y.M. (2012). The role of organizational commitment in mediating the relationship between job satisfaction and turnover intention. European Journal of Social Sciences, 30(1), 125-135.

Sangroengrob, T. \& Techachaicherdchoo, T. (2010). The impact of employee satisfaction, organization commitment and work commitment to turnover intention: A case study of it outsourcing company in Thailand, BAI Conference.

Saporna, G.C. \& Claveria, R.A. (2013). Exploring the satisfaction, commitment and turnover intentions of employees in low cost hotels in Oriental Mindoro, Philippines. Journal of Tourism Research and Hospitality, 2(1), 1-4.

Schalk, R. \& van Rijckevorsel, A. (2007). Factors influencing absenteeism and intention to leave in a call centre. New Technology, Work and Employment, 22(3), 260-274.

Sheeran, P. (2002). Intention-behaviour relations: A conceptual and empirical review. European Review of Social Psychology, 12(1), 1-36.

Sheppard, B.J., Harwick, J. \& Warshaw, P.R. (1988). The theory of reasoned action: A meta-analysis of past research with recommendations for modifications and future research. Journal of Consumer Research, 15, 324-343.

Staufenbiel, T. \& Konig, C.J. (2010). A model for the effects of job insecurity on performance, turnover intention and absenteeism. Journal of Occupational and Organizational Psychology, 83, 101-117.

Tharenou, P. (1993). A test of reciprocal causality for absenteeism. Journal of Organizational Behaviour, 14, 269-287.

The Youth Employment Network (2009). Private sector demand for youth labour in Ghana and Senegal: Study findings. Geneva: International Labour Office.

Vance, R.J. (2006). Employee engagement and commitment: A guide to understanding, measuring and increasing engagement in your organization. Alexandria, VA.: The SHRM Foundation. 
Vogelzang, C. (2008). The complexity of absenteeism and turnover intention: Direct, mediation and moderation effects. A master's thesis, University of Waikato, New Zealand.

Walker, A.S. \& Sorce, P.A. (2009). Correlates of job satisfaction of early career employees in printing and publishing occupations. Rochester, N.Y.: Printing Industry Centre.

Yao, X. \& Wang, L. (2006). The predictability of normative organizational commitment for turnover in Chinese companies: A cultural perspective. International Journal of Human Resource Management, 17(6), 1058-1075.

Yucel, I. \& Bektas, C. (2012). Job satisfaction, organizational commitment and demographic characteristics among teachers in Turkey: Younger is better? Procedia-Social and Behavioural Sciences, 46, 1598-1608. 